\title{
ANALIZA STRATEGICZNA PRZEDSIĘBIORSTWA W UKLADZIE PODEJŚĆ DO STRATEGII
}

DOI: 10.33141/po.2020.12.01

\section{Jerzy Niemczyk, Rafał Trzaska}

Przegląd Organizacji, Nr 12(971), 2020, s. 4-12 www.przegladorganizacji.pl ๑) Towarzystwo Naukowe Organizacji i Kierownictwa (TNOiK)

\section{Wprowadzenie}

$\mathbf{P}_{\mathrm{b}}$

oprawnie przeprowadzona analiza strategiczna badanego obiektu jest warunkiem zaprojektowania skutecznej strategii. Problemem praktyków zarządzania strategicznego jest bark wiedzy na temat możliwości skutecznego przeprowadzenia analizy strategicznej. $Z$ drugiej strony badacze zarządzania strategicznego nie starają się uporządkować w dostateczny sposób istniejącej wiedzy w tym obszarze. Wciąż jednak dostarczają nowych narzędzi. Trudno się zatem dziwić, że wciąż dominującym narzędziem jest analiza SWOT, czasem macierz BCG, czasem pięć sił Portera czy analiza PEST. Tymczasem w literaturze zarządzania strategicznego można zidentyfikować około 200 narzędzi analizy strategicznej (Trzaska, 2016), które powstały w obrębie zarządzania strategicznego, ale także takie, które zostały zapożyczone $\mathrm{z}$ innych nauk.

W wielu przypadkach analiza strategiczna jest wykonywana pobieżnie, wybiórczo, na bazie tylko dostępnych, łatwych do pozyskania informacji i tylko w kontekście przeszłych wyborów strategicznych. W wielu 
przypadkach jest ona tylko analitycznym dodatkiem do wcześniej „ustalonej” strategii i pełni bardzo często funkcję racjonalizacji dokonanego wyboru (Zelek, 2013). W procesie analizy strategicznej popełnia się też często jeden $\mathrm{z}$ podstawowych błędów charakterystycznych dla procesów poznawczych, błąd związany $\mathrm{z}$ wykorzystywaniem niedopasowanych do problemu narzędzi analizy i niewłaściwych z punktu widzenia kontekstu działania danego podmiotu.

Większość dostępnych narzędzi badawczych składających się na instrumentarium metod i technik analizy strategicznej powstało $\mathrm{w}$ celu rozwiązania określonego problemu praktyki zarządzania. $\mathrm{Z}$ naukowego punktu widzenia powstało wraz z pojawieniem się nowych paradygmatów postrzegania badanej organizacji i warunków osiągania przez nią sukcesów. Tymczasem w praktyce zarządzania strategicznego analitycy używają tych narzędzi jako uniwersalnych i pasujących do każdego splotu uwarunkowań działania organizacji. Nie umniejsza to idei poszukiwania holistycznego narzędzia obejmującego całość zagadnień analizy strategicznej niezależnie od kontekstowości (Romanowska, 2018).

Celem artykułu jest wskazanie na potrzebę dopasowania metod i technik analizy strategicznej do określonego i dominującego w danym miejscu i czasie wzorca kryteriów oceny sukcesu organizacji i warunków jego osiągania przez organizację (określonego podejścia do strategii). Celem utylitarnym jest wskazanie procedur analizy strategicznej dopasowanych do warunków działania organizacji. W opinii autorów, wiedza ta powinna poszerzyć epistemologię i metodologię zarządzania strategicznego. Artykuł jest rekapitulacją wieloletnich doświadczeń autorów artykułu związanych z analizami procesów projektowania strategii organizacji, a sformułowane wnioski są efektem dedukcji.

W większości podręczników zarządzania strategicznego przyjęła się opinia, że badania podejść do strategii są przede wszystkim przedmiotem zainteresowania badaczy historii zarządzania strategicznego. Dlatego też wielu autorów wyliczających podejścia do strategii traktuje ich analizy głównie jako próbę uporządkowania wiedzy w zakresie zarządzania strategicznego, jej systematyzacji i podstaw do szukania uogólnień. W niewielu pracach spotkać można się ze stwierdzeniami wskazującymi na teoretyczne i utylitarne walory takiej interpretacji wiedzy o strategiach.

Punktem wyjścia propozycji badawczej zawartej w artykule jest założenie o potrzebie dopasowania procedury i instrumentarium metod oraz technik analizy strategicznej do kontekstu działania organizacji. Tylko wtedy będzie możliwe poprawne zinterpretowanie uwarunkowań projektowania strategii danej organizacji i przyjęcie jedynie poprawnej strategii. Oczywiście przyjęcie takiego założenia wymaga wskazania kolejnych.

Po pierwsze, rozwój zarządzania strategicznego odbywa się poprzez kolejne zmiany w podejściach do strategii formułowane na gruncie teorii, ale obrazujące również zmiany w praktyce zarządzania. Przy czym historycznie starsze podejścia nie zanikają, tylko wraz z nowymi budują nowe przestrzenie analityczne w zarządzaniu strategicznym.

Po drugie, nowym podejściom do strategii towarzyszą nowe lub zmienione metody i techniki analizy strategicznej, nowe lub zmodyfikowane kryteria oceny efektywności oraz nowe lub zmodyfikowane strategie działania.

Po trzecie, cel strategiczny będzie rozumiany jako zamierzony, świadomy i pożądany stan rzeczy (sukces), do którego dążą właściciele lub szerzej interesariusze organizacji, a strategia będzie przyjętym przez daną organizację sposobem osiągnięcia tego celu.

I po czwarte, skuteczna identyfikacja lub projekcja strategii działania wymaga uwzględnienia we wszystkich fazach analizy strategicznej dominującego podejścia, właściwego dla kontekstu działania analizowanej organizacji.

\section{Układ podejść do strategii z perspektywy renty ekonomicznej}

W polskiej i zagranicznej literaturze przedmiotu można spotkać wiele propozycji systematyzacji, klasyfikacji czy strukturyzacji podejść do strategii. W polskiej literaturze przedmiotu najszerszy przegląd paradygmatów strategii można odnaleźć w pracach J. Niemczyka (2013a), A. Zakrzewskiej-Bielawskiej (2014), R. Krupskiego (2003) i K. Obłója (2007). W literaturze zagranicznej klasyką są zestawienia zaproponowane przez H. Mintzberga, B. Ahlstranda i J. Lampela (1998), B. Richardsona (1994) i C.K. Prahalada (1994) i G. Hamela (1944). Za każdą z przedstawionych propozycji klasyfikacji podejść do strategii stoi konkretne kryterium czy też logika reprezentowana przez danego autora.

W opinii J. Niemczyka (2013b), jedną z najciekawszych propozycji demarkacji istniejących podejść, ale też predykcji nowych, jest obecna przede wszystkim w teorii ekonomii kategoria renty ekonomicznej (rys. 1). Renta ekonomiczna wskazuje na podstawowe źródło osiągania ekonomicznego sukcesu organizacji, przede wszystkim organizacji gospodarczej, pozwala wyraźnie podkreślić dominujący cel poszukiwań źródeł przewag danego przedsięwzięcia. Strategia jest „ciągłym poszukiwaniem renty” (Bowman, 1973), a to, jaka renta w danym okresie jest preferowana, zależy od etapu rozwoju ekonomii i zarządzania, zarówno w ich wymiarach teoretycznych, jak i praktycznych. W pracy „Strategia. Od planu do sieci” (Niemczyk, 2013a) wskazano pięć podejść (ujęć) do strategii (rys. 1). Ta propozycja zostanie omówiona szerzej z uwagi na wykorzystanie jej do rekonfiguracji analiz strategicznych zaproponowanych w niniejszym artykule.

Renta ricardiańska i renta chamberlinowska pozwalają wyróżnić trzy klasyczne podejścia do strategii: planistyczne, pozycyjne i zasobowe.

Ujęcie planistyczne to okres pomiędzy drugą wojną światową a rokiem 1973 będącym początkiem kryzysu naftowego lat 70 . XX wieku. Charakterystyczną cechą 


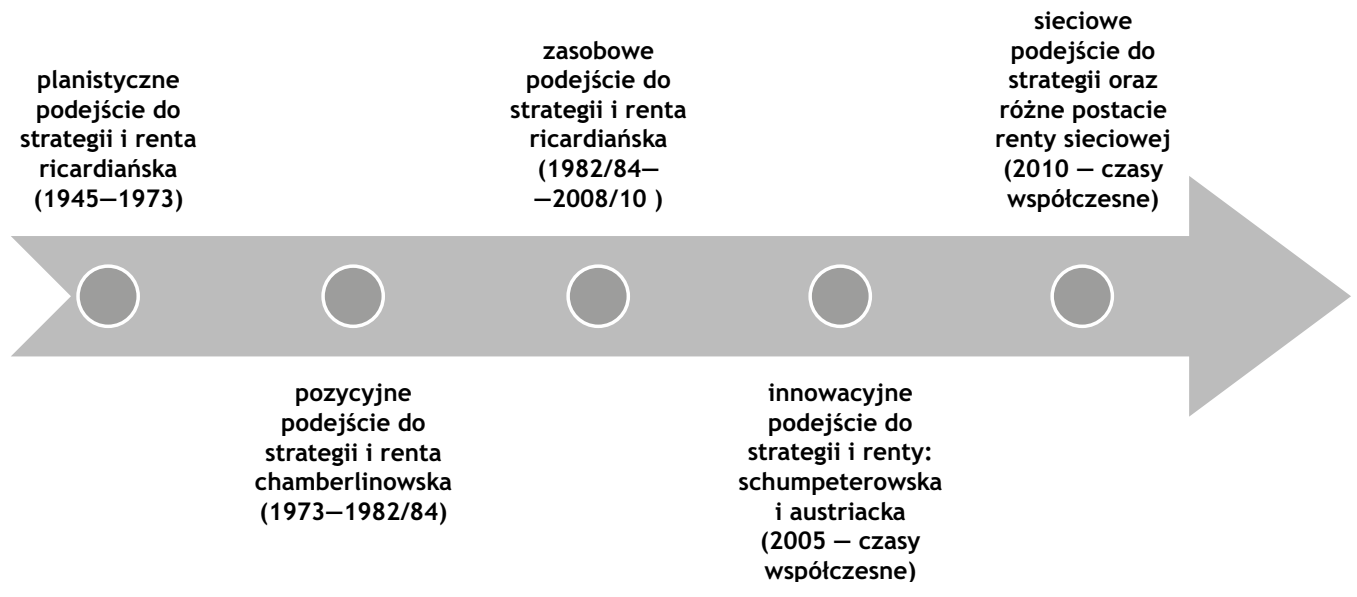

Rys. 1. Ewolucja podejść do strategii

Źródło: opracowanie własne na podstawie: Niemczyk, 2013a

tego podejścia jest orientacja na osiąganie przez organizację efektów krzywej doświadczenia skomunikowanej z ekonomią skali. Razem z charakterystyczną cechą renty ricardiańskiej, czyli koncentracją na rzadkich zasobach, podejście to stwarzało potrzebę takiego sformułowania koncepcji analizy strategicznej, by pozwalała ona odkryć rzadkie zasoby i jednocześnie wskazać długoterminową ścieżkę ich rozwoju umożliwiającą wykorzystanie krzywej doświadczenia i ekonomii, skali. Stąd pojawiły się analizy SWOT, PEST, macierz Ansoffa i inne narzędzia analizy strategicznej podejścia planistycznego.

Drugie $\mathrm{z}$ ujęć to ujęcie pozycyjne. To okres pomiędzy latami 1973 a 1982/1984. W literaturze anglosaskiej to podejście funkcjonuje pod nazwą Industry analysis. Tutaj kluczem sukcesu było osiągnięcie przez organizację określonego udziału rynkowego, gwarantującego sukces w postaci premii monopolistycznej lub prostej renty $\mathrm{z}$ tytułu określonej przewagi konkurencyjnej. $\mathrm{O}$ ile $\mathrm{w}$ podejściu planistycznym istniejąca konkurencja nie była aż tak istotna $\mathrm{w}$ analizie strategicznej, o tyle w tym nabrała wartości podstawowej. Stąd w ujęciu pozycyjnym uwzględnione są analiza 5 sił Portera, mapy grup strategicznych, łańcuch wartości i inne narzędzia analizy sektora. Specyficzną grupą narzędzi w tym podejściu były metody analizy portfelowej zapoczątkowane przez analizę BCG. Odwoływały się one do koncepcji portfela Markowitza i zwracały uwagę na ocenę ryzyka i użyteczności w projektowaniu strategii.

Podejście zasobowe obejmuje lata 1982/1984 - 2008/2010. W swych założeniach jest ono bliskie podejściu planistycznemu. W polskiej literaturze prekursorem w badaniach tego podejścia był R. Krupski (2009). W podejściu zasobowym wskazuje na potrzebę koncentracji na rzadkich (kluczowych) zasobach, przy czym poszerza zakres wykorzystywanych zasobów o zasoby niematerialne typu: marka, aktywa niematerialne, wizerunek, kompetencje i zdolności, wcześniej niedoceniane $\mathrm{w}$ budowaniu sukcesu organizacji. Inną różnicą jest sama definicja sukcesu organizacji. W podejściach planistycznym i pozycyjnym sukcesem jest osiągnięcie określonego poziomu zysku definiowanego jako różnica między przychodami i kosztami ze sprzedaży. W podejściu zasobowym, za sprawą Johna Welcha, celem stała się orientacja na budowanie wartości dla akcjonariuszy (zysku ekonomicznego), z czasem poszerzona do skali innych interesariuszy organizacji. W ujęciu zasobowym pojawiło się niewiele nowych metod i technik analizy strategicznej. Są to: analiza VRIO, model canvas, analiza interesariuszy, analiza kluczowych kompetencji i metody oraz techniki odwołujące się do analizy finansowej związanej z budowaniem wartości dla stakeholders.

Po roku $2000 \mathrm{w}$ zarządzaniu strategicznym pojawiły się nowe podejścia do strategii. Na bazie renty schumpeterowskiej wyodrębniło się podejście innowacyjne. Wskazywało ono na potrzebę budowania sukcesu organizacji dzięki koncentracji na rewolucyjnych i przełomowych innowacjach. Przy czym w odróżnieniu od wcześniejszych ujęć innowacji koncentrujących się na produkcie i technologii to podejście wskazuje na potrzebę innowacji biznesowych, marketingowych, finansowych oraz potrzebę wykorzystywania w zarządzaniu koncepcji otwartych innowacji, przełomowych innowacji i dyfuzyjnego modelu innowacji.

Ostatnim, piątym podejściem jest podejście sieciowe, którego rozwój obserwujemy $\mathrm{w}$ drugiej i prawdopodobnie będziemy jeszcze obserwować w trzeciej dekadzie XXI wieku (Niemczyk i in., 2012; Czakon, 2011). W przypadku tego podejścia identyfikuje się przede wszystkim klasyczną rentę wynikającą z minimalizacji kosztów transakcyjnych. Istotne są jednak jeszcze inne rodzaje rent: renta $\mathrm{z}$ tytułu konwergencji, renta $\mathrm{z}$ tytułu apriopriacji, renta $\mathrm{z}$ tytułu dyfuzji wiedzy oraz renty wynikające $\mathrm{z}$ funkcjonowania sieci wartości i efektu sieciowego. W tym podejściu szeroko korzysta się $\mathrm{z}$ metod klasy SNA, metod analizy interesariuszy, metod analizy usieciowienia i innych.

Te pięć podejść do strategii stanowi podstawę propozycji strukturyzacji procedury analizy strategicznej i wskazywania metod i technik analizy dedykowanych konkretnej procedurze identyfikacji strategii. Wybór tych podejść wynika $\mathrm{z}$ faktu ich utylitarnego 
charakteru odwołującego się do kryteriów efektywności, pozwalającego jednoznacznie przypisać wymienione podejścia do analizowanych strategii organizacji i tym samym zbudować logiczny i racjonalny układ procedury analizy strategicznej.

\section{Procedura analizy strategicznej z perspektywy podejść o strategii}

$\mathbf{P}$

ropozycja badawcza wskazująca procedury analizy strategicznej dopasowanej do warunków działania organizacji obejmuje trzy podstawowe etapy.

Pierwszy etap związany jest $\mathrm{z}$ identyfikacją podejścia do strategii dopasowanego do sytuacji, w której działa dana organizacja. Jest to etap poszukiwania odpowiedzi na pytanie, który rodzaj renty ekonomicznej będzie właściwy jako podstawa budowania strategii badanej organizacji. Oczywiście w wielu przypadkach wybranie tylko jednego podejścia będzie trudne. Zdarzają się bowiem biznesy i organizacje klasy non profit funkcjonujące $\mathrm{w}$ różnych przestrzeniach ekonomicznych, preferujących zbliżone lub odmienne sposoby osiągania sukcesów. Zdarzyć się może również potrzeba analizy nowego przedsięwzięcia, trudnego do sklasyfikowania $\mathrm{w}$ istniejącym układzie rent. Nie oznacza to braku przydatności tego podetapu, a jedynie potrzebę większej precyzji lub przeprowadzenia analizy w oparciu o więcej niż jedną analizę strategiczną.

Drugi etap zawiera skończoną sekwencję kroków przedstawiających charakterystyczne metody i techniki analizy strategicznej właściwej dla danej procedury analizy strategicznej skomunikowanej z podejściem do strategii.

Trzeci etap jest klasycznym etapem analizy strategicznej przedsiębiorstwa, w którym następuje formułowanie prognoz rozwoju sytuacji, które pozwolą na projektowanie strategii danego przedsiębiorstwa oraz budowanie celów organizacyjnych. Ostatni krok jest klasycznym krokiem analizy strategicznej szczegółowo opisanym w literaturze przedmiotu. Dlatego też nie będzie przedmiotem analizy w tym artykule.

Wskazana procedura na etapie identyfikacji dominującego podejścia do strategii dopasowanego do kontekstu działania analizowanej organizacji obejmuje:

- przeprowadzenie wstępnej identyfikacji kontekstu działania badanej organizacji, np. w oparciu o analizę ewolucji dotychczasowych strategii danej organizacji (tab. 1),

- wybór ekspertów,

- przyporządkowanie przez ekspertów ocen cząstkowych w oparciu o wyróżniki podejść do strategii zamieszczonej w tabeli 1 ,

- zsumowanie ocen cząstkowych,

- wskazanie dominującego podejścia do strategii i podejścia pomocniczego (uzupełniającego) dopasowanego do kontekstu działania analizowanej organizacji.

Podstawą analityczną etapu pierwszego jest tabela 1. $\mathrm{W}$ tej tabeli przedstawiono koncepcję analityczną w postaci układu pięciu podejść do strategii zawierającą w kolumnach ogólny opis danego podejścia wraz z latami historycznej dominacji. Tabela skonstruowana jest $\mathrm{w}$ charakterystyczny sposób. Odwołuje się ona do podejścia zaproponowanego w swojej pracy doktorskiej przez M. Jasińskiego (2020). Jest jego znaczną modyfikacją i reinterpretacją.

W pierwszej kolumnie tabeli 1 figuruje nazwa jednego z pięciu podejść do strategii. W kolumnie drugiej wskazano cechy renty ekonomicznej właściwej dla danego podejścia do strategii podkreślające ogólną orientację strategii organizacji. W kolumnie trzeciej, najważniejszej z punku widzenia celu analizy, wyliczono każdorazowo po osiem wyróżników każdego z wymienionych podejść do strategii. Wyróżniki te zidentyfikowano w oparciu o analizę literaturową dotyczącą konkretnych podejść do strategii, doświadczenia związane z prowadzeniem badań podejść do strategii oraz propozycję badawczą M. Jasińskiego zawartą w rozprawie doktorskiej „Identyfikacja podejść do strategii $\mathrm{w}$ przedsiębiorstwach $\mathrm{w}$ sektorze produktów spożywczych FMCG. Ujęcie metodyczne" (Jasiński, 2020). Niemniej, jest to miejsce, w którym następuje ocena wykorzystania wymienionych wyróżników w budowaniu strategii $w$ badanej organizacji. Oceny tej najlepiej dokonać w oparciu o analizę ewolucji dotychczasowych strategii danej organizacji.

W procedurze oceny możliwe są różne podejścia. Pierwsze z nich może polegać na zliczeniu pozytywnych wyborów w obrębie każdego podejścia i wskazaniu tego, który będzie miał najwięcej pozytywnych wskazań. Druga propozycja sprowadza się do oceny w skali Likerta występowania poszczególnych wyróżników i zsumowaniu ocen w poszczególnych podejściach. Jeszcze inna może polegać na wykorzystaniu metody uwzględniającej obok skali punktowej także przypisanie określonych wag poszczególnym wyróżnikom strategii.

Podejście do strategii, które otrzyma najwięcej punktów, będzie podejściem dominującym i wyznaczającym konieczność wykorzystania określonej procedury analizy strategicznej (drugi podetap). Kolejne podejście, jeśli różnica punktowa $\mathrm{w}$ stosunku do podejścia dominującego jest niewielka, może być pomocniczo wykorzystane w całościowej analizie strategicznej.

Etap analizy strategicznej z wykorzystaniem metod i technik analizy strategicznej właściwych dla danego podejścia do strategii zawiera właściwą już sekwencję etapów analizy strategicznej. Podstawowy schemat analityczny jest tutaj niezmienny i nawiązuje do klasycznych etapów analizy strategicznej. Obejmuje więc:

- określenie oczekiwanych celów strategicznych,

- właściwą analizę strategiczną z wykorzystaniem metod i technik analizy strategicznej,

- identyfikację strategii osiągnięcia celów strategicznych,

- określenie celów szczegółowych, wskaźników sukcesu dla wybranych celów szczegółowych i programów działania.

Poniżej w układzie szczegółowych procedur analizy strategicznej przedstawiono pięć propozycji strykturyzacji tego etapu odniesionych do zidentyfikowanych pieciu podejść do strategii. 
Tabela 1. Metoda identyfikacji dominującego podejścia do strategii dopasowanego do kontekstu działania analizowanej organizacji (podstawowe założenia)

\begin{tabular}{|c|c|c|}
\hline $\begin{array}{l}\text { Typ podejścia } \\
\text { do strategii } \\
\text { wraz z okresem } \\
\text { dominacji } \\
\text { podejścia }\end{array}$ & $\begin{array}{l}\text { Wyróżniki celu } \\
\text { strategicznego }\end{array}$ & Wyróżniki podejścia do strategii \\
\hline \multirow{8}{*}{$\begin{array}{l}\text { Planistyczne } \\
\text { podejście do } \\
\text { strategii } \\
(1945-1973)\end{array}$} & \multirow{8}{*}{$\begin{array}{l}\text { Orientacja na } \\
\text { korzyściach krzywej } \\
\text { doświadczenia } \\
\text { i ekonomii skali }\end{array}$} & wskazywanie w strategii sposobów zwiększania ekonomizacji działań (przychody a koszty) \\
\hline & & $\begin{array}{l}\text { dominacja w opisie strategii kategorii: plan, długoterminowość, koszty produkcji, dywersyfikacja } \\
\text { produktowa }\end{array}$ \\
\hline & & budowanie efektywności na bazie korzyści krzywej doświadczenia i ekonomii skali \\
\hline & & nastawienie na długoterminowe planowanie działań \\
\hline & & stosowanie kryteriów dywersyfikacji opartych o wytyczną ekonomii skali lub zakresu \\
\hline & & stosowanie kryteriów outsourcingu opartych na kalkulacji kosztów produkcji \\
\hline & & dominacja wśród menedżerów najwyższego szczebla menedżerów pionów produkcji \\
\hline & & stawianie w doborze kadr na specjalistów w zawodach inżynierskich \\
\hline \multirow{8}{*}{$\begin{array}{l}\text { Pozycyjne podejście } \\
\text { do strategii } \\
(1973-1982 / 1984)\end{array}$} & \multirow{8}{*}{$\begin{array}{l}\text { Orientacja na } \\
\text { zwiększanie } \\
\text { udziałów } \\
\text { rynkowych, } \\
\text { koncentracja na } \\
\text { budowaniu przewagi } \\
\text { konkurencyjnej }\end{array}$} & podkreślanie w strategiach źródeł przewagi konkurencyjnej \\
\hline & & budowanie efektywności poprzez zwiększanie udziałów rynkowych \\
\hline & & dominacja w opisie strategii kategorii: sektor, segment, przewaga, bariery wejścia, ryzyko \\
\hline & & stosowanie kryteriów dywersyfikacji opartych o portfele produktów \\
\hline & & stosowanie kryteriów outsourcingu opartych na kalkulacji kosztów \\
\hline & & dominacja wśród menedżerów najwyższego szczebla menedżerów z wykształceniem finansowym \\
\hline & & stawianie w doborze kadr na specjalistów w zawodach inżynierskich i finansistów \\
\hline & & dominacja metod analizy typu: 5 sił Portera, metody portfelowe (BCG, ADL) \\
\hline \multirow{9}{*}{$\begin{array}{l}\text { Zasobowe podejście } \\
\text { do strategii } \\
(1982 / 1984- \\
-2008 / 2010)\end{array}$} & \multirow{9}{*}{$\begin{array}{l}\text { Orientacja na } \\
\text { budowanie } \\
\text { wartości organizacji } \\
\text { w wymiarze } \\
\text { wartości } \\
\text { ekonomicznej }\end{array}$} & podkreślanie w strategii znaczenia kluczowych kompetencji \\
\hline & & $\begin{array}{l}\text { dominacja w opisie strategii kategorii: zasoby, kluczowe kompetencje, budowanie wartości, kapitał } \\
\text { ludzki, model biznesowy, KPI, kluczowe procesy }\end{array}$ \\
\hline & & $\begin{array}{l}\text { orientacja na budowanie wartości marki, aktywów niematerialnych, wizerunku, kompetencji } \\
\text { i zdolności }\end{array}$ \\
\hline & & dbałość o interesariuszy i relacje z interesariuszami (znaczenie relacji inwestorskich) \\
\hline & & $\begin{array}{l}\text { koncentracja w działaniach na finansowych sposobach budowania wartości rynkowej firmy (EVA, } \\
\text { EBIDTA) }\end{array}$ \\
\hline & & stosowanie kryteriów dywersyfikacji bazujących na kluczowych kompetencjach \\
\hline & & $\begin{array}{l}\text { stosowanie kryteriów outsourcingu zorientowanych na usuwanie obszarów niebudujących wartości } \\
\text { organizacji }\end{array}$ \\
\hline & & dominacja wśród menedżerów najwyższego szczebla finansistów \\
\hline & & $\begin{array}{l}\text { dominacja metod analizy typu: łańcuch wartości, VRIO, model biznesowy CANVAS, analiza } \\
\text { interesariuszy }\end{array}$ \\
\hline \multirow{8}{*}{$\begin{array}{l}\text { Innowacyjno- } \\
\text { przedsiębiorcze } \\
\text { podejście } \\
\text { do strategii } \\
\text { (2005 - czasy } \\
\text { współczesne) }\end{array}$} & \multirow{8}{*}{$\begin{array}{l}\text { Orientacja na } \\
\text { rewolucyjne } \\
\text { i przełomowe } \\
\text { innowacje }\end{array}$} & dominacja w opisie strategii kategorii: innowacja, procesy, wartość intelektualna \\
\hline & & $\begin{array}{l}\text { budowanie efektywności na bazie ciągłego generowania innowacji produktowych, technologicznych, } \\
\text { biznesowych, finansowych i innych }\end{array}$ \\
\hline & & polityka otwartych innowacji \\
\hline & & $\begin{array}{l}\text { stosowanie kryteriów dywersyfikacji opartych o wytyczną poszukiwania źródeł innowacji lub } \\
\text { obszarów „blue ocean” i wytyczne koopetycji }\end{array}$ \\
\hline & & $\begin{array}{l}\text { stosowanie kryteriów outsourcingu opartych na chronieniu innowacyjnych i trudnych do } \\
\text { skopiowania działań }\end{array}$ \\
\hline & & zarządzanie talentami \\
\hline & & zarządzanie działaniami zamiast zarządzania wynikami \\
\hline & & stawianie na myślenie typu agile (zwinność, zdolność do szybkiej reakcji) \\
\hline
\end{tabular}




\begin{tabular}{|c|c|c|}
\hline $\begin{array}{l}\text { Typ podejścia } \\
\text { do strategii } \\
\text { wraz z okresem } \\
\text { dominacji } \\
\text { podejścia }\end{array}$ & $\begin{array}{l}\text { Wyróżniki celu } \\
\text { strategicznego }\end{array}$ & Wyróżniki podejścia do strategii \\
\hline \multirow{8}{*}{$\begin{array}{l}\text { Sieciowe podejście } \\
\text { do strategii } \\
\text { (2010 - czasy } \\
\text { współczesne) }\end{array}$} & \multirow{8}{*}{$\begin{array}{l}\text { Orientacja na } \\
\text { budowanie sieci } \\
\text { współzależnych } \\
\text { i współdzielących } \\
\text { zasoby i wartości } \\
\text { organizacji }\end{array}$} & dominacja w opisie strategii kategorii: sieć, relacje, interesariusze \\
\hline & & $\begin{array}{l}\text { dominacja efektywności bazującej na budowaniu sieci kontraktów, sieci wartości, wykorzystaniu } \\
\text { efektu sieciowego, }\end{array}$ \\
\hline & & $\begin{array}{l}\text { stosowanie kryteriów dywersyfikacji opartych na wykorzystaniu efektu sieciowego, włączenia } \\
\text { kolejnych grup klientów }\end{array}$ \\
\hline & & $\begin{array}{l}\text { stosowanie kryteriów outsourcingu opartych na kalkulacji stopnia dopasowania biznesu do cech } \\
\text { budowanej sieci lub budowanego ekosystemu }\end{array}$ \\
\hline & & dominacja metod analizy typu: SNA, analiza sieci \\
\hline & & stawianie w doborze kadr na menedżerów z pionów informatycznych \\
\hline & & serwicyzacja usług, otwartość na technologie 4.0 \\
\hline & & operowanie kategoriami: klaster, centra usług, parki technologiczne, Industry 4.0 \\
\hline
\end{tabular}

Źródło: opracowanie własne na podstawie propozycji badawczej zaproponowanej przez M. Jasińskiego (2020)

\section{Analiza strategiczna w planistycznym podejściu do strategii}

Procedura planistycznej analizy strategicznej:

1. Określenie celów strategicznych analizowanej organizacji w postaci oczekiwanej wielkości produkcji i wielkości zysku.

2. Przeprowadzenie analizy PEST w celu określenia potencjalnych zmiennych wpływających na czynniki związane z popytem i podażą.

3. Skorzystanie $z$ metod i narzędzi klasy: SWOT, PEST, macierz Ansoffa, punktowa ocena czynników wewnętrznych, analizy ekonomiczne oraz finansowe zasobów organizacji i analiza cyklu życia.

4. Zidentyfikowanie podstawowych zasobów organizacji spośród zasobów materialnych.

5. Zidentyfikowanie podstawowych działań /procesów/ funkcji przedsiębiorstwa.

6. Zbudowanie strategii planistycznej w postaci:

a) albo wskazania określonego sposobu ekonomizacji działania (ważne dla firm zorientowanych na uzyskanie korzyści efektu skali),

b) albo wskazania określonej strategii spośród strategii w układzie macierzy Ansoffa,

c) albo wskazania określonej strategii w układzie faz cyklu życia produktu.

7. Określenie:
a) celów szczegółowych,
b) wskaźników o cechach KPI dla wybranych celów szczegółowych,
c) programów działania (bazujących na wybranej strategii).

\section{Analiza strategiczna w pozycyjnym podejściu do strategii}

Procedura pozycyjnej analizy strategicznej:

1. Określenie celów strategicznych analizowanej organizacji w postaci oczekiwanego poziomu rentowności.
2. Wybór sektora. Opisanie sektora w układzie statycznym i dynamicznym poprzez analizy typu desk research.

3. Przeprowadzenie analizy 5 sił Portera i wskazanie satysfakcjonującego ze względu na oczekiwany poziom rentowności rodzaju sektora lub jego części.

4. Sporządzenie mapy grup strategicznych dla sektora (alternatywnie).

5. Sporządzenie portfeli strategicznych w oparciu o metody portfelowe (alternatywnie).

6. Skorzystanie $\mathrm{z}$ metod i technik analizy klasy: analiza 5 sił Portera, mapy grup strategicznych, łańcuch wartości, macierz BCG, macierz McKinseya oraz inne metody portfelowe.

7. Ustalenie źródeł przewagi konkurencyjnej możliwej do osiągnięcia w sektorze przy wykorzystaniu propozycji strategii ogólnych M. Portera lub innych koncepcji klasyfikacji strategii charakterystycznych dla podejścia pozycyjnego.

8. Określenie:

a) celów szczegółowych,

b) wskaźników o cechach KPI dla wybranych celów szczegółowych,

c) programów działania (bazujących na wybranej strategii).

\section{Analiza strategiczna w zasobowym podejściu do strategii}

Procedura zasobowej analizy strategicznej:

1. Określenie celów strategicznych poprzez wskazanie interesariuszy i ich oczekiwań w analizowanej organizacji. Określenie oczekiwanego poziomu wartości dla interesariuszy.

2. Identyfikacja zasobów organizacji, zarówno materialnych i niematerialnych.

3. Hierarchizacja zasobów $\mathrm{z}$ wykorzystaniem podejścia VRIO. 
4. Skorzystanie $\mathrm{z}$ metod i technik analizy klasy: metody analizy portfela technologicznego, punktowa ocena zdolności konkurencyjnych firmy, strategiczna analiza luki, bilans strategiczny, analiza kapitału intelektualnego, macierz M.H. Zacka, Balance Scored Card i model canvas.

5. Zbudowanie strategii zasobowej w układzie:

a) zhierarchizowanych zasobów i ich wpływu na wartość dla interesariuszy,

b) albo kluczowych procesów i ich wpływu na wartość dla interesariuszy,

c) albo kluczowych partnerów i ich wpływu na wartość dla interesariuszy.

6. Określenie:

a) celów szczegółowych,

b) wskaźników KPI dla wybranych celów szczegółowych,

c) programów działania (bazujących na wybranej strategii).

\section{Analiza strategiczna w innowacyjnym podejściu do strategii}

Procedura innowacyjnej analizy strategicznej:

1. Określenie znaczenia innowacyjności w analizowanej organizacji.

2. Skorzystanie z koncepcji” otwartych innowacji, przełomowych innowacji, dyfuzyjnego modelu innowacji lub koncepcji „blue ocean”.

3. Skorzystanie $\mathrm{z}$ metod i technik analizy klasy: metody kreatywnego myślenia, metody „canvas”, model „blue ocean”, metoda identyfikacji „disruptive innovation opportunities” (Narasimhalu, 2012), mapa drogowa technologii i partnerstwa (Caetano, Amaral, 2011) lub Design Thinking.

4. Zbudowanie strategii innowacji w postaci:

a) preferowanych rodzajów innowacji (innowacje przełomowe, innowacje produktowe, innowacje modelu biznesowego, innowacje typu „blue ocean”),

b) albo preferowanych źródeł innowacji (innowacje otwarte i innowacje zamknięte),

c) albo preferowanego czasu życia innowacji.

5. Określenie:

a) celów szczegółowych,

b) wskaźników KPI dla wybranych celów szczegółowych,

c) programów działania (bazujących na wybranej strategii)

\section{Analiza strategiczna w sieciowym podejściu do strategii}

Procedura sieciowej analizy strategicznej:

1. Wskazanie celów strategicznych analizowanej organizacji w postaci oczekiwanego wzrostu wartości organizacji i sieci, której częścią jest analizowana organizacja.

2. Identyfikacja właściwych rent sieciowych budujących wartość analizowanej organizacji.
3. Skorzystanie $\mathrm{z}$ metod i technik analizy klasy: metody SNA, metody analizy interesariuszy, model analizy usieciowienia, analiza sieci wartości (Value Net, PARTS), sieciowy model oceny przepływów między sektorami (McNerney i in., 2013) lub Deloitte Enterprise Value Map.

4. Zbudowanie strategii sieciowej w postaci:

a) wyboru zakresu wykorzystania struktur hierarchicznych verus rynkowych (renta z kosztów transakcyjnych),

b) wskazania rodzajów apriopriacji (rodzaj interesariuszy i rodzaj przejmowanej wartości),

c) wykazania preferowanych kanałów dyfuzji wiedzy,

d) wskazania rodzaju sieci wartości spośród: łańcucha wartości, warsztatu i sieci wartości,

e) sposobów generowania efektu sieciowego.

5. Określenie:

a) celów szczegółowych,

b) wskaźników KPI dla wybranych celów szczegółowych,

c) programów działania (bazujących na wybranej strategii).

Przedstawione propozycje strukturyzacji poszczególnych etapów są o tyle nieskończonymi propozycjami analitycznymi, o ile można się spodziewać odkrywania wciąż nowych metod i technik analizy strategicznej i odkrywania nowych podejść do strategii.

\section{Podsumowanie}

7 arządzanie strategiczne jest jednym $\mathrm{z}$ najbardziej in teresujących obszarów nauk o zarządzaniu i jakości. Wynika to $\mathrm{z}$ interdyscyplinarnego charakteru zarządzania strategicznego. Łączy ono bowiem wiedzę z wszystkich dyscyplin dziedziny nauk społecznych, w tym szczególnie z: nauk o zarządzaniu i jakości, ekonomii i finansów, nauk prawnych i nauk o polityce i administracji. Efektem tej szczególnej koopetycji nauk społecznych jest potrzeba precyzyjnego użytkowania różnych metod, technik i narzędzi wykorzystywanych w zarządzaniu strategicznym. Niestety, w wielu przypadkach związanych z wykorzystaniem wiedzy z zarządzania strategicznego spotykamy się z sytuacjami niedopasowania, braku uwzględniania kontekstu, pobieżnego przeprowadzania analiz i wynikającego $\mathrm{z}$ tych błędów nieuprawnionego wnioskowania. Przykładem takiego zawodnego postępowania jest powszechne wykorzystywanie technik analizy strategicznej powstałych $\mathrm{w}$ okresie upowszechniania się podejścia pozycyjnego we wszystkich innych kontekstach analitycznych, nawet wtedy, gdy nie jesteśmy $\mathrm{w}$ stanie, nie możemy podać precyzyjnie granic badanego sektora lub w przypadku gdy granice sektora zostały kompletnie rozmyte.

Przedstawione procedury w swej głównej konstrukcji są podobne. Różnice pomiędzy nimi dotyczą w szczególności: rodzaju uzyskiwanej renty, zakresów wykorzystywanej wiedzy eksperckiej, liczby narzędzi strategicznych możliwych do wykorzystania, rodzaju dostępnych 
Tabela 2. Porównanie procedur analiz strategicznych bazujących na różnych podejściach do strategii

\begin{tabular}{|c|c|c|c|c|c|}
\hline $\begin{array}{r}\begin{array}{r}\text { Rodzaj analizy } \\
\text { strategicznej }\end{array} \\
\text { Kryteria oceny }\end{array}$ & $\begin{array}{c}\text { Analiza } \\
\text { strategiczna } \\
\text { w planistycznym } \\
\text { podejściu do } \\
\text { strategii }\end{array}$ & $\begin{array}{c}\text { Analiza } \\
\text { strategiczna } \\
\text { w pozycyjnym } \\
\text { podejściu do } \\
\text { strategii }\end{array}$ & $\begin{array}{c}\text { Analiza } \\
\text { strategiczna } \\
\text { w zasobowym } \\
\text { podejściu do } \\
\text { strategii }\end{array}$ & $\begin{array}{c}\text { Analiza } \\
\text { strategiczna } \\
\text { w innowacyjnym } \\
\text { podejściu do } \\
\text { strategii }\end{array}$ & $\begin{array}{c}\text { Analiza } \\
\text { strategiczna } \\
\text { w sieciowym } \\
\text { podejściu do } \\
\text { strategii }\end{array}$ \\
\hline Rodzaj uzyskiwanej renty & renta ricardiańska & $\begin{array}{l}\text { renta } \\
\text { chamberlinowska }\end{array}$ & renta ricardiańska & $\begin{array}{l}\text { renta } \\
\text { schumpeterowska }\end{array}$ & renty sieciowe \\
\hline Zakres wiedzy eksperckiej & $\begin{array}{l}\text { nauki o zarządzaniu } \\
\text { i jakości, ekonomia } \\
\text { i finanse, także } \\
\text { nauki inżynieryjno- } \\
\text {-techniczne }\end{array}$ & $\begin{array}{l}\text { nauki o zarządzaniu } \\
\text { i jakości, ekonomia } \\
\text { i finanse }\end{array}$ & $\begin{array}{l}\text { nauki o zarządzaniu } \\
\text { i jakości, ekonomia } \\
\text { i finanse, inne nauki } \\
\text { społeczne }\end{array}$ & $\begin{array}{l}\text { nauki o zarządzaniu } \\
\text { i jakości, ekonomia } \\
\text { i finanse, inne } \\
\text { nauki społeczne, } \\
\text { także informatyka } \\
\text { i matematyka }\end{array}$ & $\begin{array}{l}\text { nauki o zarządzaniu } \\
\text { i jakości, ekonomia } \\
\text { i finanse, inne } \\
\text { nauki społeczne, } \\
\text { także informatyka } \\
\text { i matematyka }\end{array}$ \\
\hline $\begin{array}{l}\text { Liczba i rodzaje narzędzi } \\
\text { analizy strategicznej }\end{array}$ & $\begin{array}{l}\text { niewiele } \\
\text { oryginalnych } \\
\text { dla zarządzania } \\
\text { strategicznego } \\
\text { narzędzi analizy } \\
\text { strategicznej; wiele } \\
\text { innych narzędzi, } \\
\text { odwołujących się do } \\
\text { dorobku ekonomii } \\
\text { i ekonomiki firmy }\end{array}$ & $\begin{array}{l}\text { wiele oryginalnych } \\
\text { dla zarządzania } \\
\text { strategicznego } \\
\text { narzędzi analizy } \\
\text { strategicznej } \\
\text { zbudowanych m.in. } \\
\text { przez M. Portera }\end{array}$ & $\begin{array}{l}\text { niewiele } \\
\text { oryginalnych } \\
\text { dla zarządzania } \\
\text { strategicznego } \\
\text { narzędzi analizy } \\
\text { strategicznej, } \\
\text { wiele innych } \\
\text { narzędzi analizy } \\
\text { odwołujących się } \\
\text { m.in. do Value } \\
\text { Based Management }\end{array}$ & $\begin{array}{l}\text { niewiele } \\
\text { oryginalnych } \\
\text { dla zarządzania } \\
\text { strategicznego } \\
\text { narzędzi analizy } \\
\text { strategicznej }\end{array}$ & $\begin{array}{l}\text { niewiele } \\
\text { oryginalnych } \\
\text { dla zarządzania } \\
\text { strategicznego } \\
\text { narzędzi analizy } \\
\text { strategicznej, } \\
\text { wiele innych } \\
\text { narzędzi analizy } \\
\text { odwołujących się } \\
\text { do dorobku nauk } \\
\text { socjologicznych, } \\
\text { matematyki } \\
\text { i informatyki }\end{array}$ \\
\hline $\begin{array}{l}\text { Rodzaj dostępnych } \\
\text { typologii strategii }\end{array}$ & $\begin{array}{l}\text { typologie strategii } \\
\text { produktowo- } \\
\text {-rynkowych }\end{array}$ & $\begin{array}{l}\text { typologie strategii } \\
\text { produktowo- } \\
\text {-rynkowych }\end{array}$ & $\begin{array}{l}\text { typologie strategii } \\
\text { kompetencyjno- } \\
\text {-rynkowych }\end{array}$ & $\begin{array}{l}\text { typologie strategii } \\
\text { bazujące na ideach } \\
\text { przełomowych } \\
\text { innowacji } \\
\text { i otwartych } \\
\text { innowacji }\end{array}$ & $\begin{array}{l}\text { typologie } \\
\text { strategii bazujące } \\
\text { na układach } \\
\text { konkurencji, } \\
\text { koopetycji } \\
\text { i współpracy }\end{array}$ \\
\hline Zakres wykorzystania & $\begin{array}{l}\text { sektory } \\
\text { tradycyjne, sektory } \\
\text { produkcyjne, } \\
\text { sektory znajdujące } \\
\text { się w fazie } \\
\text { dojrzałości, sektory } \\
\text { regulowane, } \\
\text { organizacje } \\
\text { publiczne }\end{array}$ & $\begin{array}{l}\text { sektory o wyraźnie } \\
\text { zdefiniowanych } \\
\text { granicach, } \\
\text { sektory poddające } \\
\text { się procesom } \\
\text { koncentracji }\end{array}$ & $\begin{array}{l}\text { sektory szybko } \\
\text { rosnące, sektory } \\
\text { z rozmytymi } \\
\text { granicami, } \\
\text { sektory usług, } \\
\text { sektory bazujące } \\
\text { na zasobach } \\
\text { niematerialnych }\end{array}$ & $\begin{array}{l}\text { sektory } \\
\text { technologiczne, } \\
\text { sektory znajdujące } \\
\text { się w fazie wzrostu, } \\
\text { nowe sektory, } \\
\text { startupy }\end{array}$ & $\begin{array}{l}\text { sektory } \\
\text { technologiczne, } \\
\text { ekosystemy, sektory } \\
\text { usług, sektory } \\
\text { znajdujące się } \\
\text { w fazie wzrostu, } \\
\text { startupy }\end{array}$ \\
\hline
\end{tabular}

Źródło: opracowanie własne

typologii strategii i zakresu wykorzystania w praktyce. Analiza informacji zawartych w tabeli 2 wskazuje na interdysplinarność zarządzania strategicznego. Dostrzec to można w zakresie wykorzystywanej wiedzy eksperckiej i liczbie oraz rodzaju stosowanych narzędzi analizy strategicznej. Zarządzanie strategiczne wciąż nie wypracowało zbyt wielu własnych narzędzi oceny strategii i kontekstu zarządzania strategicznego. Widać to zwłaszcza w nowszych podejściach, które czerpią szeroko $\mathrm{z}$ nauk ścisłych i innych nauk społecznych. Jednocześnie $\mathrm{z}$ analizy zakresu wykorzystywania wymienionych $\mathrm{w}$ artykule procedur wynika, że rośnie zapotrzebowanie na procedury dedykowane węższym obszarom działalności, konkretnym firmom czy konkretnym ekosystemom. Silnie spersonalizowane procedury to prawdopodobnie interesujący kierunek rozwoju metod i narzędzi analizy strategicznej.
Celem tego artykułu było przedstawienie rozwiązań eliminujących podaną zawodność. Według autorów artykułu kluczem do rozwiązania problemu jest precyzyjne dopasowanie metod i technik analizy strategicznej do określonego kontekstu działania badanej organizacji. Pomocnym w tym dopasowaniu jest skorzystanie z dorobku wiedzy sfokusowanej wokół tzw. podejść do strategii. W przyjętym w artykule założeniu badawczym podejście do strategii jest uogólnionym teoretycznie kontekstem praktycznych wyznaczników skutecznego działania organizacji. Przedstawione propozycje strukturyzacji procedur analiz strategicznych adekwatnie do zidentyfikowanego dla danej organizacji dominującego sposobu myślenia o strategii (podejścia do strategii) mają charakter utylitarny i powinny służyć właściwemu przeprowadzeniu analizy strategicznej. 
Podstawowym wnioskiem płynącym z tej prezentacji wyników badań jest zalecenie precyzyjnego dobierania metod i technik analizy strategicznej do kontekstu działania badanej organizacji, kontekstu opisanego cechami podejść do strategii, w tym w szczególności wskazania kryteriów osiągania sukcesu badanej organizacji.

\section{prof. dr hab. Jerzy Niemczyk Uniwersytet Ekonomiczny we Wrocławiu Wydział Zarzadzania ORCID: 000-0002-0766-3929 e-mail: jerzy.niemczyk@ue.wroc.pl}

\section{dr Rafał Trzaska \\ Uniwersytet Ekonomiczny we Wrocławiu \\ Wydział Zarządzania \\ ORCID: 0000-0003-0261-7496 \\ e-mail: rafal.trzaska@ue.wroc.pl}

\section{Bibliografia}

[1] Bowman E.H. (1973), Epistemology, Corporate Strategy, and Academe, Working Paper, Alfred P. Sloan School of Management.

[2] Caetano M., Amaral D.C. (2011), Roadmapping for Technology Push and Partnership: A Contribution for Open Innovation Environment, „Technovation”, Vol. 31, No. 7, pp. 320-335.

[3] Czakon W. (2011), Paradygmat sieciowy w naukach o zarzadzaniu, „Przegląd Organizacji”, Nr 11, s. 3-6.

[4] Jasiński M. (2020), Identyfikacja podejść do strategii $w$ przedsiębiorstwach $w$ sektorze produktów spożywczych FMCG. Ujęcie metodyczne, materiały niepublikowane, Rozprawa doktorska, Uniwersytet Ekonomiczny we Wrocławiu, Wrocław.

[5] Krupski R. (red.), (2003), Zarzadzanie strategiczne: koncepcje-metody, Wydawnictwo Akademii Ekonomicznej im. Oskara Langego, Wrocław.

[6] Krupski R. (2009), O szkole zasobów zarządzania strategicznego inaczej, „Przegląd Organizacji”, Nr 3, s. 5-7.

[7] McNerney J., Fath B.D., Silverberg G. (2013), Network Structure of Inter-industry Flows, „Physica A: Statistical Mechanics and Its Applications", Vol. 392, No. 24, pp. 6427-6441.

[8] Mintzberg H., Ahlstrand B., Lampel J. (1998), Strategy safari. A Guided Tour through the Wilds of Strategic Management, Prentice Hall, New York.

[9] Obłój K. (2007), Strategia organizacji, PWE, Warszawa.

[10] Narasimhalu A.D. (2012), Innovation Rules: A Method for Identifying Disruptive Innovation Opportunities? International Society for Professional Innovation Management, Conference, Barcelona.

[11] Niemczyk J., Stańczyk-Hugiet E., Jasiński B. (2012), Sieci międzyorganizacyjne. Wspótczesne wyzwanie dla teorii i praktyki zarządzania, C.H. Beck, Warszawa.
[12] Niemczyk J. (2013a), Strategia. Od planu do sieci, Wydawnictwo Uniwersytetu Ekonomicznego, Wrocław.

[13] Niemczyk J. (2013b), Ujęcia zarządzania strategicznego z perspektywy renty ekonomicznej, „Prace Naukowe Wałbrzyskiej Wyższej Szkoły Zarządzania i Przedsiębiorczości”, Nr 22, s. 77-83.

[14] Prahalad C.K., Hamel G. (1994), Strategy as a Field of Stu$d y$ : Why Search for a New Paradigm? „Strategic Management Journal", No. 15(S2), pp. 5-16.

[15] Romanowska M. (2018), Idea spójności w zarządzaniu strategicznym, „Przegląd Organizacji”, Nr 6, s. 3-9.

[16] Richardson B. (1994), Crisis Management and Management Strategy-Time to „Loop the Loop”? „Disaster Prevention and Management: An International Journal”, No. 3, pp. 59-80.

[17] Trzaska R. (2016), Model analizy strategicznej w podejściu sieciowym, Rozprawa doktorska, Uniwersytet Ekonomiczny we Wrocławiu, Wrocław.

[18] Zakrzewska-Bielawska A. (2014), Ewolucja szkół strategii: przegląd głównych podejść i koncepcji, „Prace Naukowe Wałbrzyskiej Wyższej Szkoły Zarządzania i Przedsiębiorczości”, Nr 27, s. 9-29.

[19] Zelek A. (2013), Dekalog współczesnego stratega - krytyczne błędy zarządzania strategicznego $w$ praktyce, „Zeszyty Naukowe Politechniki Łódzkiej, Organizacja i Zarządzanie", Nr 52(1147), s. 73-84.

\section{Strategic Analysis of Enterprise in the Structure of Approaches to Strategy}

\section{Summary}

The aim of the article is to indicate the need to adjust the methods and techniques of strategic analysis to the specific and dominant in a given place and time approach to the strategy understood as a set of criteria and conditions for achieving success by an organisation, measured by the type of economic rent obtained. The utilitarian goal of the article is to indicate effective strategic analysis procedures adjusted to the conditions of the organisation's operation. The article is the result of many years of observations regarding the processes of designing an organisation's strategy, in which the authors of the articles participated and analysed from the perspective of strategic analysis procedures and various phases of strategy design.

The article develops a layer of strategic analysis instruments connected with approaches to strategy. At the same time, it indicates specific stages of such an analysis and specific methods and tools of strategic analysis, characteristic of a given strategy logic. In the opinion of the authors, this knowledge should broaden the area of epistemology and methodology of strategic management.

\section{Keywords}

strategic management, organisational strategies, strategic analysis 